S.S. Rudenko, D.G. Koliushko, O.V. Kashcheyev

\title{
DETERMINATION OF DIRECTION TO RECONSTRUCTION OF GROUNDING SYSTEM
}

\begin{abstract}
Purpose. In paper the most efficient and economical way for bringing the grounding system of power facilities into compliance with requirements of normative parameters was determined. Methodology. The determination was based on the comparison of the calculated values of touch voltage and length of additional electrodes for reconstruction of grounding system by two ways. To calculate the software based on the method of point current source which located in the three-layer soil, method guidance potential, Gauss method and the method of ordinary least squares was used. Results. For three possible cases amount of material and labor costs for the reconstruction and modernization of the grounding system while maintaining the equipotent grounding system and allowable touch voltage was defined. Originality. For the first time the effectiveness the reconstruction of grounding system for requirements of touch voltage, not to her of resistance, both in terms of electrical safety and in terms of material and labor costs proved. Practical value. The implementation of results saves a national scale funds for modernization and reconstruction of existing grounding systems of power facilities. References 3, tables 8, figures 6.

Key words: grounding system, electrical safety, reconstruction, material and labour costs.
\end{abstract}

На основании расчетного эксперимента проанализированы возможные случаи несоответствия заземляющих устройств нормативным требованиям и способы их реконструкции по требованиям к напряжению прикосновения и сопротивлению. Определена эффективность указанных направлений реконструкции как с точки зрения электробезопасности, так и материально-трудовых затрат. Библ. 3, табл. 8, рис. 6.

Ключевые слова: заземляющее устройство, электробезопасность, реконструкция, материально-трудовые затраты.

Introduction. Substations (SS) operated in Ukraine, most were designed for the requirements of the permissible value of resistance of grounding device (GD). Since these energy facilities were built over 30 years ago, it has undergone significant changes GD influenced corrosion processes, replacement and reconstruction of high-voltage equipment and so on. Therefore, at this time you need to choose the best option of GD modernization according to one of its normalized parameters (NP). To bring the current GD in line with current regulations [1] uses electromagnetic diagnostics (EMD) of the state of GD [2] which aims to determine the NP of GD and development of recommendations on reconstruction and modernization of GD.

Reconstruction of GD of electrical installation for voltage above $1 \mathrm{kV}$ in power grids with dull grounded neutral, as well as the design can be done in two ways [2]: according to the requirements of the GD allowable resistance values or the permissible touch voltage. Existing investigations [3] have repeatedly noted that in some cases of GD realization according to its resistance can not guarantee the electrical safety of staff and provide a valid value of touch voltage. But this time estimate material and labor costs, taking into account the values of NP to select the optimal arrangement direction of GD is not performed.

The goal of the work is determining the optimal direction of reconstruction and modernization of electrical grounding device of electrical installations of voltage above $1 \mathrm{kV}$ working in a network with dull grounded neutral.

Materials of investigation. We consider two methods of reconstruction of existing grounding device: the first one - the requirements for its resistance, the second one - the requirements to touch voltage. Analysis of the development of recommendations by these two ways to perform the reconstruction of GD we carry out on the example of electrical substation of voltage class of
110 (150) $\mathrm{kV}$. It was considered three options:

1)before the reconstruction of exceeding the permissible touch voltage observed in $50 \%$ of the equipment after the reconstruction of both the first and second contact means voltage does not exceed the permissible value;

2) before the reconstruction of exceeding the permissible touch voltage observed on all equipment to ensure acceptable touch voltage in the reconstruction of both the first and second insulating layer methods used in the field of surgical equipment maintenance;

3 ) before the reconstruction of contact voltage and impedance GD do not exceed the allowable values and during the reconstruction of the first and second method required only made constructive recommendations.

We consider these options in detail:

1) After the reconstruction of two ways of contact voltage does not exceed the permissible value.

We execute analysis on the example of existing substation, the results of which EMD state GD are shown in Fig. 1, 2. This thick solid black line marked grounding located underground. The real name of the research facility is changed to conditional - SS No. 1.

Initial data for determining NP of GD were: real circuit GD SS No. 11, in use, the electrical characteristics $(\mathrm{ECH})$ of ground (electrical resistivity (ER) I layer $42.65 \Omega \cdot \mathrm{m}$, II layer $-25.37 \Omega \cdot \mathrm{m}$ and thickness of the first layer $-0.82 \mathrm{~m})$, the value of current single-phase short circuit (SC) $-1.957 \mathrm{kA}$. It should be noted that the implementation of reconstruction GD exceeding the allowable contact voltage $(65 \mathrm{~V}$ at the time of operation of reserve protection with more than 1.0) was observed in $50 \%$ of the equipment where possible operational switching (namely: BI T-1, BI T-2, S T-1, S T-2 and SC1 ), while the resistance value GD does not exceed the allowable value of $0.5 \Omega$. 


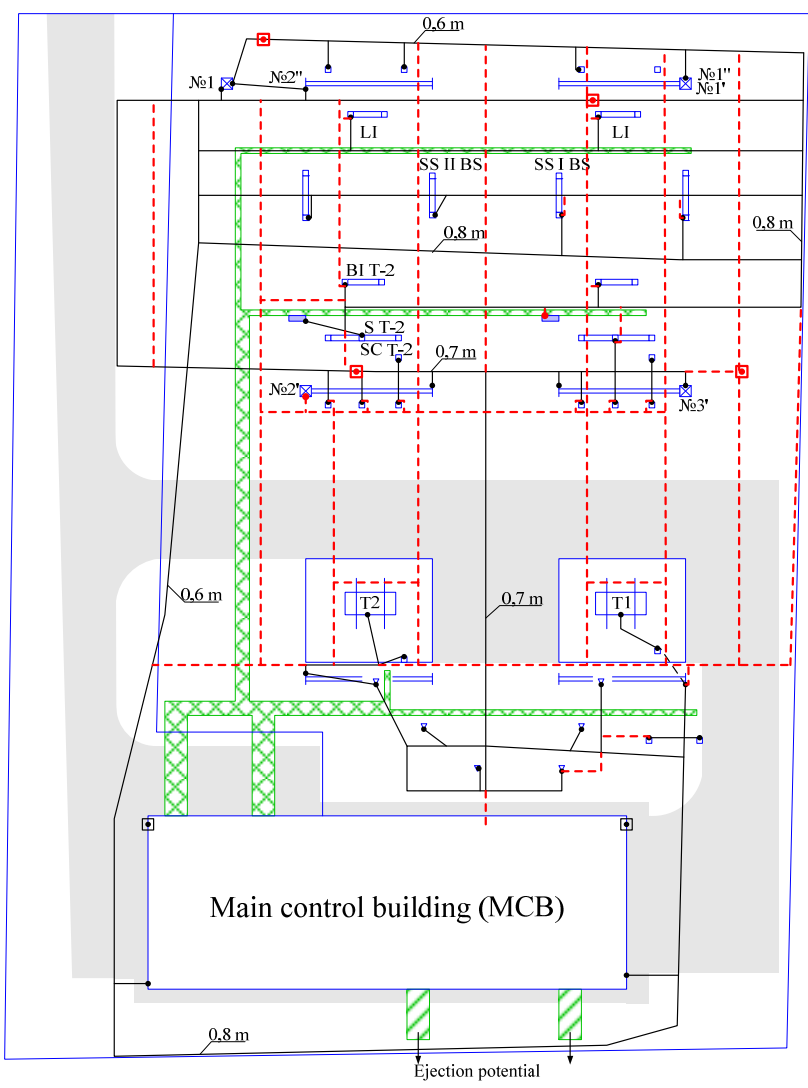

Fig. 1. Circuit of the GD of the SS No. 1 complied with the permissible resistance value

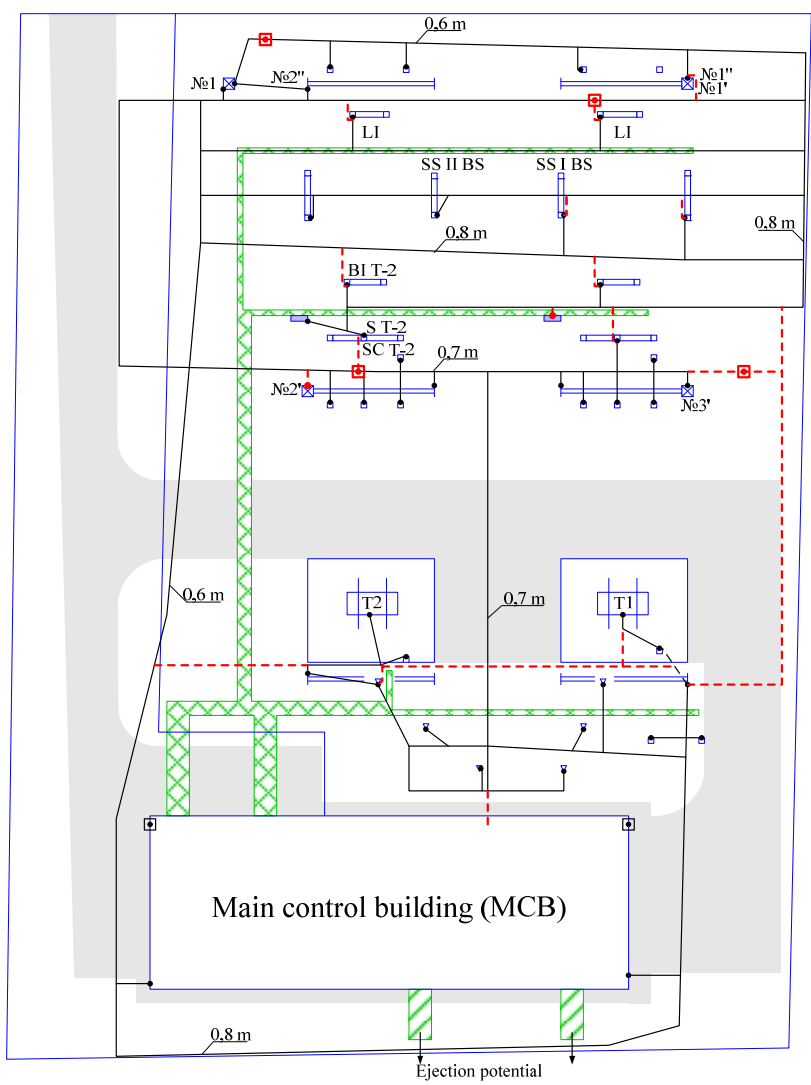

Fig. 2. Circuit of the GD of the SS No. 1 complied with the permissible touch voltage value

According to the item 1.7.106 of the Standard [1] the distance between the transverse horizontal grounding
(HG) for GD performed the requirements for its resistance, it is recommended to take upward from the periphery to the center grounding grid. In this case, the first and following distance from the periphery should not exceed respectively $4.0 ; 5.0 ; 6.0 ; 7.5 ; 9.0 ; 11.0 ; 13.5$; $16.0 ; 20.0 \mathrm{~m}$. The depth should be laying HG $(0.5-0.7)$ m. Fig. 1 shows the GD of the substation with introduced recommendations necessary to bring embodiment of the GD to the requirements of its resistance $R_{G}$ (additional HG are indicated by dotted line).

According to the item 1.7.105 of the above standard for GD performed according to the requirements to touch voltage $U_{t}$ we must place the longitudinal and transverse HG to perform protective potential equalization considering permissible touch voltage value and convenience joining grounded equipment, laying depth must be not less than $0.3 \mathrm{~m}$. Thus, in comparison with $\mathrm{GD}$, meet the requirements for its resistance requirements for a design less stringent.

Fig. 2 shows GD with recommendations necessary to bring it into compliance with the allowable voltage to ground. Calculation of parameters was performed using mathematical tools developed in [4]. Compare the value (see Table 1) and a voltage variation of contact for both versions of the GD. From Table 1 it follows that the voltage of touch with the first mode of implementation will be somewhat less important, but in both cases touch voltage does not exceed the permissible value of $65 \mathrm{~V}$, and variations in the voltage of contact is approximately the same for both cases, i.e. in the first and in the second case will be equipotential grounding grid.

Table 1

\begin{tabular}{|c|c|c|c|c|}
\hline \multirow{2}{*}{$\begin{array}{c}\text { Equipment } \\
\text { name }\end{array}$} & \multicolumn{2}{|c|}{$\begin{array}{c}\text { Values of } U_{t}, \mathrm{~V} \\
\text { requirements } \\
\text { ror } R_{G}\end{array}$} & $\begin{array}{c}\text { GD with } \\
\text { requirements } \\
\text { for } U_{t}\end{array}$ & $\begin{array}{c}\text { Deviations of } U_{t} \text { from } \\
\text { mean value } \%\end{array}$ \\
\begin{tabular}{c|c} 
requirements \\
for $R_{G}$
\end{tabular} & $\begin{array}{c}\text { GD with } \\
\text { requirements } \\
\text { for } U_{t}\end{array}$ \\
\hline SS II BS & 26.1 & 38.3 & 12.8 & 9.9 \\
\hline SS I BS & 23.5 & 33.8 & 1.6 & -2.9 \\
\hline BI T-2 & 22.0 & 32.4 & -4.9 & -7.0 \\
\hline S T-2 & 21.1 & 27.5 & -8.8 & -21.1 \\
\hline SC T-2 & 20.6 & 31.6 & -10.9 & -9.3 \\
\hline SC T-1 & 21.2 & 34.2 & -8.3 & -1.8 \\
\hline right LI & 25.6 & 39.8 & 12.4 & 2.8 \\
\hline left LI & 26.6 & 37.1 & -19.6 & -13.9 \\
\hline
\end{tabular}

When performing the first method of reconstruction GD material and labor costs (see Table 2) will be significantly higher (more than five times).

Table 2

\begin{tabular}{|c|c|c|c|}
\hline \multicolumn{2}{|c|}{ Name and type of works } & $\begin{array}{l}\text { GD with } \\
\text { requirements } \\
\text { for } R_{G}\end{array}$ & $\begin{array}{l}\text { GD with } \\
\text { requirements } \\
\text { for } U_{t}\end{array}$ \\
\hline \multicolumn{2}{|c|}{$\begin{array}{l}\text { Laying additional HG } \\
\text { in soil of } 3 \text { group, } m\end{array}$} & 349 & 66 \\
\hline \multicolumn{2}{|c|}{$\begin{array}{l}\text { Laying additional HG } \\
\text { in soil of } 5 \text { group, } m\end{array}$} & 151 & 33 \\
\hline \multirow{2}{*}{$\begin{array}{l}\text { Fulfillment of } \\
\text { punctures under } \\
\text { roads or pass on } \\
\text { the asphalt- } \\
\text { concrete } \\
\text { massive }\end{array}$} & amount & 9 & 2 \\
\hline & $\begin{array}{l}\text { length, } \\
\mathrm{m}\end{array}$ & 60 & 10 \\
\hline
\end{tabular}


2) For permissible touch voltage in the reconstruction of both the first and the second insulating layer methods used in the field of surgical equipment maintenance.

We execute analysis on the example of existing substation, the results of which EMD state GD are shown in Fig. 3, 4. This thick solid black line marked grounding located underground. The real name of the research object changed to conditional - SS No. 2.

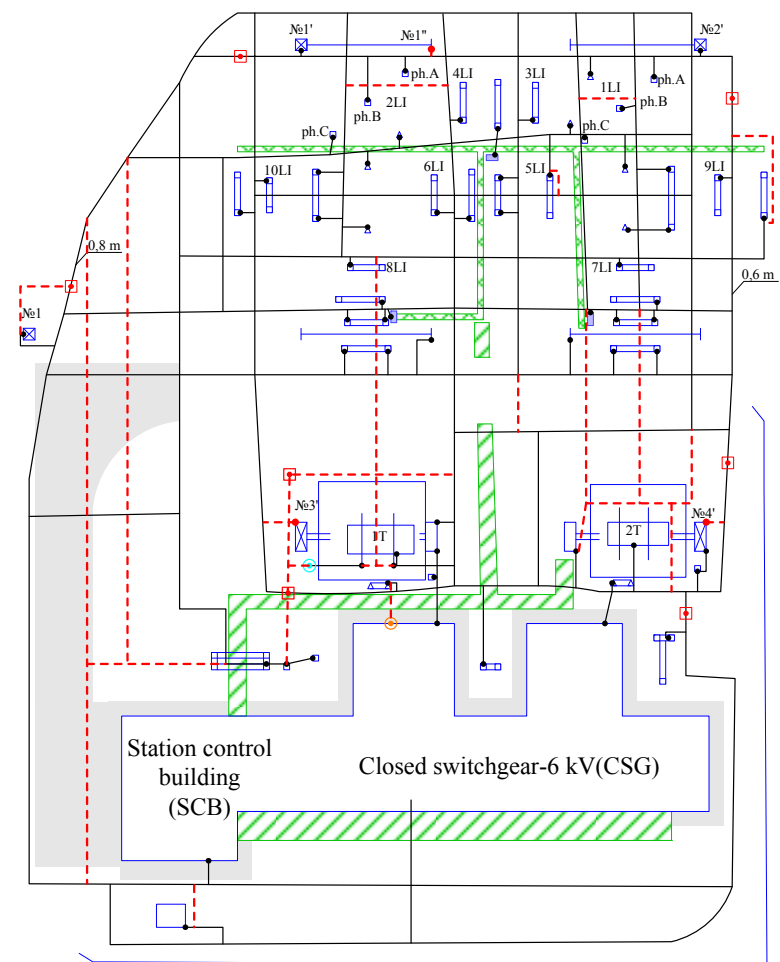

Fig. 3. Circuit of the GD of the SS No. 2 complied with the permissible resistance value

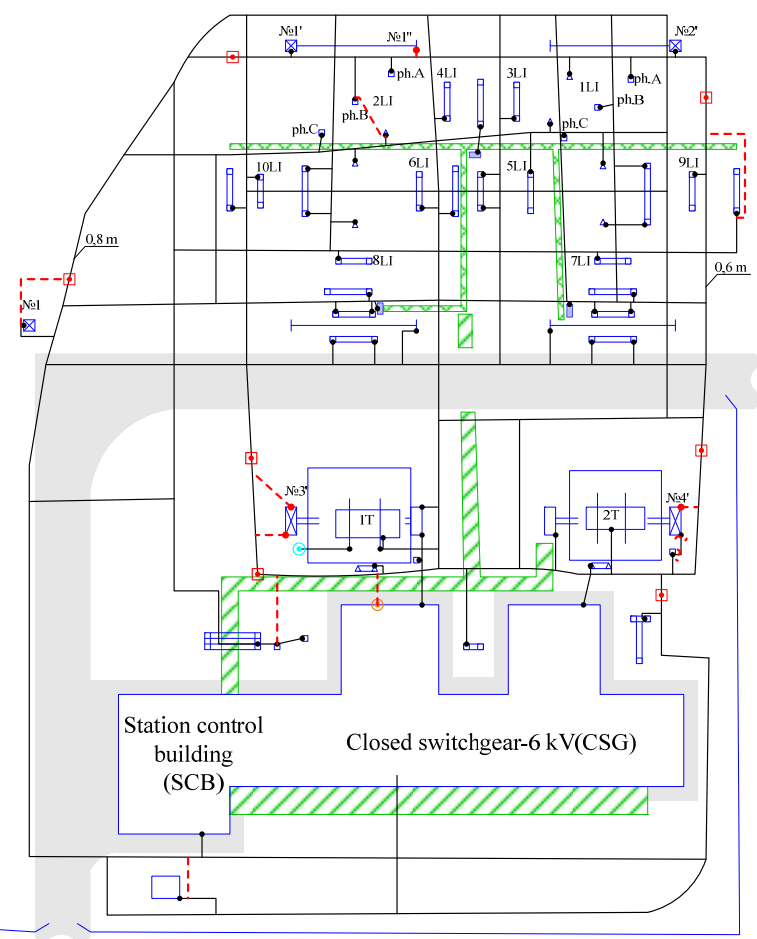

Fig. 4. Circuit of the GD of the SS No. 2 complied with the permissible touch voltage value
Initial data for determining NP GD were: real circuit GD SS No. 2, in use, ECH ground (ER layer I - $33 \Omega \cdot \mathrm{m}$, II layer $-4.6 \Omega \cdot \mathrm{m}$ and thickness of the first layer -1.97 $\mathrm{m}$, the value of current single-phase circuit - $10.784 \mathrm{kA}$. It should be noted that the implementation of reconstruction GD exceeding the allowable contact voltage $(65 \mathrm{~V}$ at the time of operation of reserve protection $0.1 \mathrm{~s}$ ) was observed on all equipment where possible rapid switching, although the resistance value of GD does not exceed the permissible $0.5 \Omega$.

Fig. 3 shows the GD of the substation with introduced recommendations necessary to bring embodiment of the GD to the requirements of its resistance GD (additional HG are indicated by dotted line).

Fig. 4 shows the GD with the recommendations necessary to bring it into compliance with the allowable voltage to ground.

We compare the value and variation (see Table 3 ) of touch voltage for both versions of the GD.

From Table 3 we can see that the voltage of contact for both methods of reconstruction exceeds the permissible value of $65 \mathrm{~V}$. Therefore the use of the insulating layer required for the reconstruction of both methods in the field of equipment maintenance, thus reducing to acceptable $U_{t}$.

Table 3

\begin{tabular}{|c|c|c|c|c|}
\hline \multirow{2}{*}{$\begin{array}{c}\text { Equipment } \\
\text { name }\end{array}$} & \multicolumn{2}{|c|}{ Values of $U_{t}, \mathrm{~V}$} & \multicolumn{2}{c|}{$\begin{array}{c}\text { Deviations of } U_{t} \text { from } \\
\text { mean value, \% }\end{array}$} \\
\cline { 2 - 5 } & $\begin{array}{c}\text { GD with } \\
\text { requirements } \\
\text { for } R_{G}\end{array}$ & $\begin{array}{c}\text { GD with } \\
\text { requirements } \\
\text { for } U_{t}\end{array}$ & $\begin{array}{c}\text { GD with } \\
\text { requirements } \\
\text { for } R_{G}\end{array}$ & $\begin{array}{c}\text { GD with } \\
\text { requirements } \\
\text { for } U_{t}\end{array}$ \\
\hline 1LI ph. A & 195.5 & 208.5 & 16.2 & 8.4 \\
\hline 1LI ph. B & 137.4 & 198.4 & -18.3 & 3.2 \\
\hline 1LI ph. C & 134.5 & 155.8 & -20.1 & -19.0 \\
\hline 2LI ph. A & 152.7 & 217.3 & -9.3 & 13.0 \\
\hline 2LI ph. B & 191.9 & 185.9 & 14.0 & -3.3 \\
\hline 2LI ph. C & 196.6 & 214.0 & 16.8 & 11.3 \\
\hline 3LI & 173.4 & 189.1 & 3.0 & -1.7 \\
\hline 4LI & 180.8 & 200.7 & 7.4 & 4.4 \\
\hline 5LI & 127.5 & 174.2 & -24.2 & -9.4 \\
\hline 6LI & 185.7 & 203.4 & 10.4 & 5.8 \\
\hline 7LI & 155.7 & 168.3 & -7.5 & -12.5 \\
\hline 8LI & 171.3 & 198.8 & 1.8 & 3.4 \\
\hline 9LI & 190.2 & 201.9 & 13.0 & 5.0 \\
\hline 10LI & 162.7 & 175.8 & -3.3 & -8.6 \\
\hline
\end{tabular}

Variations in the contact pressure will be roughly the same for both cases.

In this case, when performing the first reconstruction GD way of material and labor costs for the construction of additional HG (see Table 4) will be significantly higher (more than six times). For improvement include operational service in both cases used without metal reinforcement plate with a total impedance of $3500 \Omega$.

3) Touch voltage does not exceed the permissible values, and during reconstruction included only the necessary constructive recommendations.

We execute analysis execute on the example of existing substations, the results of which EMD state GD are shown in Fig. 5, 6. This thick solid black line marked grounding located underground. The real name of the research object changed to conditional - SS No. 3 . 
Table 4

\begin{tabular}{|c|c|c|c|}
\hline \multicolumn{2}{|c|}{ Name and type of works } & $\begin{array}{l}\text { GD with } \\
\text { requirements } \\
\text { for } R_{G} \\
\end{array}$ & $\begin{array}{l}\text { GD with } \\
\text { requirements } \\
\text { for } U_{t}\end{array}$ \\
\hline \multicolumn{2}{|c|}{$\begin{array}{l}\text { Laying additional } \mathrm{HG} \\
\text { in soil of } 3 \text { group, } \mathrm{m}\end{array}$} & 199 & 32 \\
\hline \multicolumn{2}{|c|}{$\begin{array}{l}\text { Laying additional HG } \\
\text { in soil of } 5 \text { group, } m\end{array}$} & 78 & 12 \\
\hline \multirow[b]{2}{*}{$\begin{array}{l}\text { Fulfillment of } \\
\text { punctures } \\
\text { under roads or } \\
\text { pass on the } \\
\text { asphalt- } \\
\text { concrete } \\
\text { massive }\end{array}$} & Amount & 8 & 1 \\
\hline & $\begin{array}{l}\text { length, } \\
\text { m }\end{array}$ & 63 & 3 \\
\hline \multicolumn{2}{|c|}{$\begin{array}{c}\text { Number of places of } \\
\text { stacking plates } \\
\text { without reinforcement with } \\
\text { the area of } 1 \mathrm{~m}^{2}, \text { pieces }\end{array}$} & 16 & 16 \\
\hline
\end{tabular}

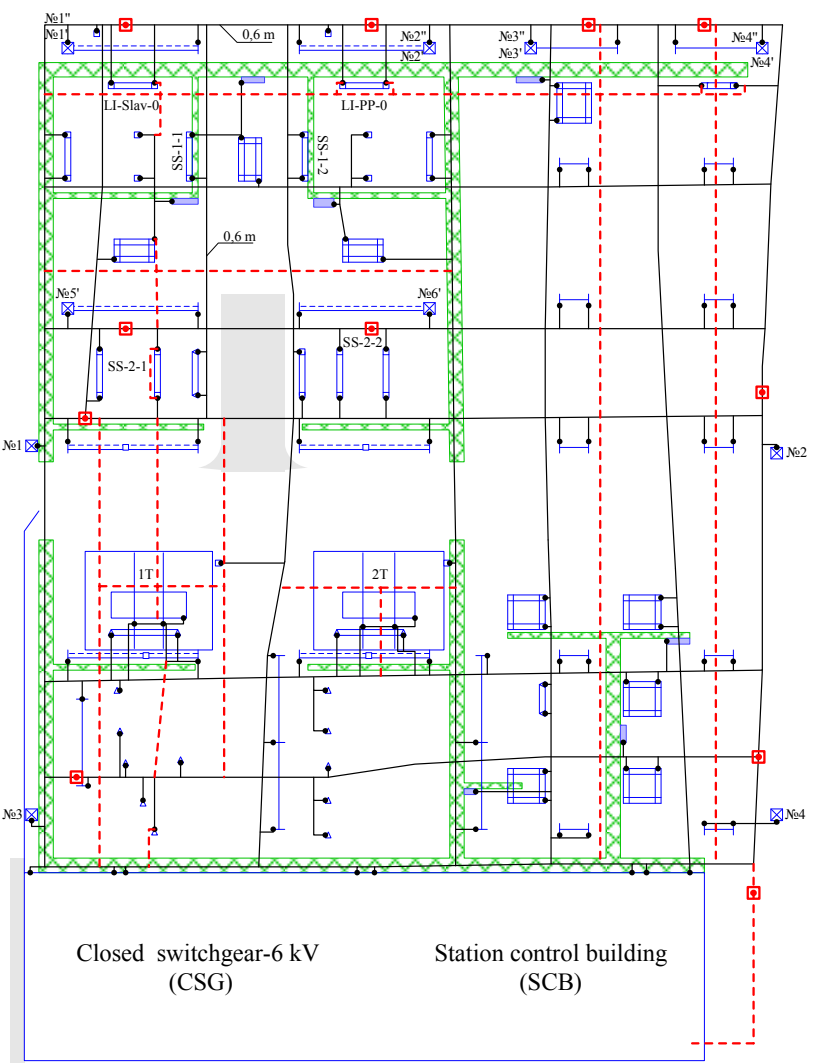

Fig. 5. Circuit of the GD of the SS No. 3 complied with the permissible resistance value

Initial data for determining the NP were: the real circuit of GD SS No. 3 (see Fig. 5), which is in operation, ECH ground (ER I layer $-12.1 \Omega \cdot \mathrm{m}$, II layer $-15.1 \Omega \cdot \mathrm{m}$, the first layer thickness $-1.15 \mathrm{~m}$ ), the value of current single-phase circuit $-3.798 \mathrm{kA}$. It should be noted that the implementation of reconstruction touch voltage does not exceed the permissible value (65 in operation at the time of backup protect more than $1.0 \mathrm{~s}$ ) on all equipment. GD resistance value was also lower than the allowable $0.5 \Omega$.

Fig. 5 shows the GD of the substation with introduced recommendations necessary to bring embodiment of the GD to the requirements of its resistance GD (additional HG are indicated by dotted line).
Fig. 6 shows GD with recommendations necessary to bring it into compliance with the allowable voltage to ground. As seen from the circuit, GD installation requires only vertical grounding connections and lightning at SCB. We compare the value and variation $U_{t}$ (see Table 5) for both versions of the GD.

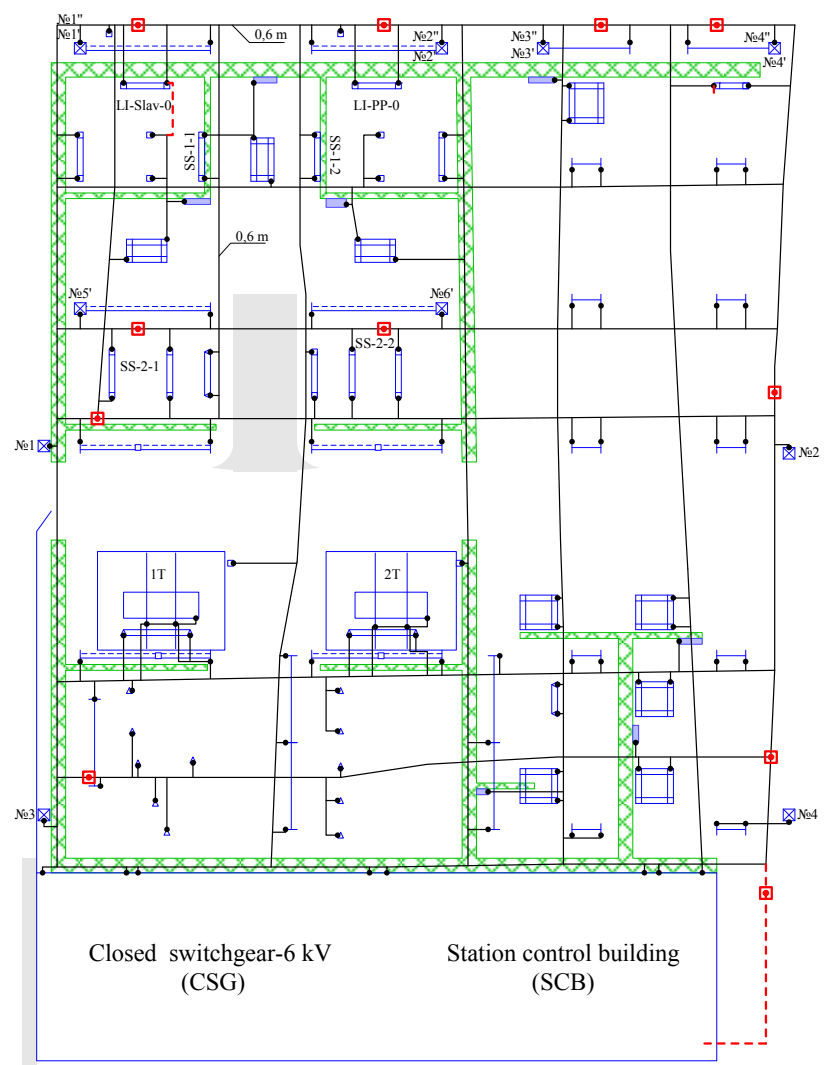

Fig. 6. Circuit of the GD of the SS No. 3 complied with the permissible touch voltage value

Table 5

\begin{tabular}{|c|c|c|c|c|}
\hline \multirow{2}{*}{$\begin{array}{c}\text { Equipment } \\
\text { name }\end{array}$} & \multicolumn{2}{|c|}{ Values of $U_{t}, \mathrm{~V}$} & \multicolumn{2}{c|}{$\begin{array}{c}\text { Deviations of } U_{t} \text { from } \\
\text { mean value, \% }\end{array}$} \\
\cline { 2 - 5 } & $\begin{array}{c}\text { GD with } \\
\text { requirements } \\
\text { for } R_{G}\end{array}$ & $\begin{array}{c}\text { GD with } \\
\text { requirements } \\
\text { for } U_{t}\end{array}$ & $\begin{array}{c}\text { GD with } \\
\text { requirements } \\
\text { for } R_{G}\end{array}$ & $\begin{array}{c}\text { GD with } \\
\text { equirements } \\
\text { for } U_{t}\end{array}$ \\
\hline LI-Slav-0 & 26.2 & 35.1 & 13.7 & 14.3 \\
\hline SS-1-1 & 23.9 & 28.2 & 3.8 & -8.1 \\
\hline LI-PP-0 & 21.7 & 37.9 & -5.8 & 23.5 \\
\hline SS-1-2 & 25.2 & 28.5 & 9.4 & -7.2 \\
\hline SS-2-1 & 18.7 & 30.2 & -18.8 & -1.6 \\
\hline SS-2-2 & 22.5 & 24.3 & -2.3 & -20.8 \\
\hline
\end{tabular}

From Table 5 follows that of contact voltage as in the first and in the second mode of execution does not exceed the permissible value of $65 \mathrm{~V}$. Also, variations in the $U_{t}$ will be approximately the same for both cases. In this case, when performing the first reconstruction GD way of material and labor costs for the construction of additional HG (see Table 6) will be almost 8 times higher.

It should be noted that the reconstruction of the GD by requirements for $R_{G}$ reduces resistance value GD only 3-6\% compared to GD reconstruction the requirements to touch voltage (see Table 7). 
Table 6

\begin{tabular}{|c|c|c|c|}
\hline \multicolumn{2}{|c|}{ Name and type of works } & $\begin{array}{l}\text { GD with } \\
\text { requirements } \\
\text { for } R_{G}\end{array}$ & $\begin{array}{l}\text { GD with } \\
\text { requirements } \\
\text { for } U_{t}\end{array}$ \\
\hline \multicolumn{2}{|c|}{$\begin{array}{l}\text { Laying additional HG } \\
\text { in soil of } 3 \text { group, } m\end{array}$} & 321 & 38 \\
\hline \multicolumn{2}{|c|}{$\begin{array}{l}\text { Laying additional HG } \\
\text { in soil of } 5 \text { group, } m\end{array}$} & 125 & 16 \\
\hline \multirow{2}{*}{$\begin{array}{l}\text { Fulfillment of } \\
\text { punctures } \\
\text { under roads or } \\
\text { pass on the } \\
\text { asphalt- } \\
\text { concrete } \\
\text { massive }\end{array}$} & Amount & 5 & - \\
\hline & $\begin{array}{l}\text { length, } \\
\text { m }\end{array}$ & 28 & - \\
\hline
\end{tabular}

Table 7

\begin{tabular}{|c|c|c|c|}
\hline \multirow[b]{2}{*}{$\begin{array}{c}\text { Substation } \\
\text { name }\end{array}$} & \multirow{2}{*}{$\begin{array}{c}R_{G} \text { before GD } \\
\text { reconstruction, } \\
\Omega\end{array}$} & \multicolumn{2}{|c|}{$R_{G}$ after GD reconstruction, $\Omega$ : } \\
\hline & & $\begin{array}{l}\text { with requirements } \\
\text { for } R_{G}\end{array}$ & $\begin{array}{l}\text { with requirements } \\
\text { for } U_{t}\end{array}$ \\
\hline & 0.309 & & \\
\hline SS & 0.088 & 0.083 & 0.087 \\
\hline SS No. 3 & 0.133 & 0.119 & 0.123 \\
\hline
\end{tabular}

According to the Standard ДСТУ Б Д.1.1-1-2013, the analysis of the cost of reconstruction of GD in two directions for the object (see Table 8) to the cost of construction of HG in the soil of different groups, and arranging the insulating layer in the event necessary, onsite equipment maintenance.

Table 8

\begin{tabular}{|c|c|c|}
\hline \multirow{2}{*}{ Substation name } & \multicolumn{2}{|c|}{$\begin{array}{c}\text { Cost of the GD reconstruction, } \\
\text { thousand UAH: }\end{array}$} \\
\cline { 2 - 3 } & with requirements for $R_{G}$ & $\begin{array}{c}\text { with requirements } \\
\text { for } U_{t}\end{array}$ \\
\hline SS No. 1 & 42.504 & 8.915 \\
\hline SS No. 2 & 29.423 & 4.640 \\
\hline SS No. 3 & 45.781 & 5.168 \\
\hline
\end{tabular}

Thus, cost-effectiveness of reconstruction and modernization of existing power facilities GD with requirement for allowable contact voltage is proven.

\section{Conclusions.}

1. Implementation of the GD with requirements for its resistance does not guarantee electrical safety of the electrical maintenance personnel in case of emergency, i.e. the resistance value of the GD does not allow one to judge the suitability of the GD for further use.

2. Reconstruction of existing GD should be carried out according to the requirements to touch voltage that will ensure electrical safety of service personnel and reliability of operating the equipment in all modes of electrical installations.

3. Implementation of modernization and reconstruction of the GD in the direction of providing acceptable touch voltage has high economic efficiency: the average savings in the reconstruction of power facilities of voltage classes of $110 \mathrm{kV}$ and $150 \mathrm{kV}$ is about 33 thousand UAH for each object.

The authors during the period 2015 - 2016 have developed recommendations for modernization and reconstruction of the GD as required for touch voltage of 10 substations of the voltage class of $150 \mathrm{kV}$ and 20 substations of voltage class $110 \mathrm{kV}$. That said introduction of the indicated direction of reconstruction allowed even for a fairly small number of substations saving more than 1 million UAH for Ukrainian energy sector.

\section{REFERENCES}

1. Natsional'nyy standart Ukrayiny. Pravila ulashtuvannya electroustanovok [National Standard of Ukraine. Electrical Installation Regulations]. Kharkiv, Minenergovugillya Ukrayiny Publ., 2014. 793 p. (Ukr).

2. Natsional'nyy standart Ukrayiny. SOU 31.2-2167768119:2009. Viprobuvannya ta kontrol' prystroyiv zazemlennya elektroustanovok. Tipova instruktsiya. [National Standard of Ukraine SOU 31.2-21677681-19:2009. Test and control devices, electrical grounding. Standard instruction]. Kyiv, Minenergovugillya Ukrayiny Publ., 2010. 54 p. (Ukr).

3. Koliushko D.G., Koliushko G.M., Rudenko S.S. Statistical analysis according grounding grid the power stations and substations for of normalized parameters. Energetic and electrification, 2015, no.6, pp. 3-7. (Rus).

4. Koliushko D.G., Rudenko S.S. Mathematical model of grounding connection of a power plant with under layer. Electronic modeling, 2014, vol.36, no.2, pp. 89-97. (Rus).

Received 13.02.2017

S.S. Rudenko ${ }^{1}$, Research Associate,

D.G. Koliushko ${ }^{1}$, Candidate of Technical Science, Senior

Research Associate,

O.V. Kashcheyev ${ }^{1}$, Candidate of Technical Science, Senior

Research Associate,

${ }^{1}$ National Technical University «Kharkiv Polytechnic Institute»,

2, Kyrpychova Str., Kharkiv, 61002, Ukraine,

e-mail: nio5_molniya@ukr.net

How to cite this article:

Rudenko S.S., Koliushko D.G., Kashcheyev O.V. Determination of direction to reconstruction of grounding system. Electrical engineering \& electromechanics, 2017, no.2, pp. 57-61. doi: 10.20998/2074-272X.2017.2.09. 